\title{
Intercalibration of mussel Mytilus edulis clearance rate measurements
}

\author{
J. Kjerulf Petersen ${ }^{1, *}$, S. Bougrier ${ }^{2, *}$, A. C. Smaal ${ }^{3}$, P. Garen ${ }^{2}$, S. Robert ${ }^{4}$, \\ J. E. N. Larsen ${ }^{1}$, E. Brummelhuis ${ }^{3}$ \\ ${ }^{1}$ National Environmental Research Institute, PO Box 358, Frederiksborgvej 399, 4000 Roskilde, Denmark \\ ${ }^{2}$ Centre de Recherche en Écologie Marine et Aquacole, IFREMER-CNRS, BP 5, 17137 La Rochelle, France \\ ${ }^{3}$ Netherlands Institute for Fisheries Research, Centre for Shellfish Research, PO Box 77, 4400 AB Yerseke, The Netherlands \\ ${ }^{4}$ Laboratoire Conchylicole de Poitou-Charentes, IFREMER, BP 133, 17390 La Tremblade, France
}

\begin{abstract}
Clearance rate (CR) was measured in blue mussels Mytilus edulis L. from Aiguillon Bay and the Oosterschelde using 3 different methods: the flow-through method, the bio-deposition method and the indirect or clearance method. CR differed significantly as a function of the method used and of the origin of the mussels. CR measured with the bio-deposition method were significantly lower than rates measured with the other methods. Results for the flow-through method depended, however, on how $\mathrm{CR}$ was calculated. $\mathrm{CR}$ using the flow-through and indirect methods was on average $10.0 \mathrm{l} \mathrm{g}^{-1} \mathrm{~h}^{-1}$ in mussels from Aiguillon Bay and $5.3 \mathrm{l} \mathrm{g}^{-1} \mathrm{~h}^{-1}$ in mussels from the Oosterschelde. The significantly lower $\mathrm{CR}$ of mussels from Oosterschelde was related to condition index and gill area, but could not entirely be explained by these factors.
\end{abstract}

KEY WORDS: Clearance rate $\cdot$ Intercalibration $\cdot$ Method $\cdot$ Mussels $\cdot$ Gill area $\cdot$ Condition

\section{INTRODUCTION}

When studying suspension-feeding bivalves in an ecological context, and especially when modelling their impact on the biological structure of the coastal zone, it is important to estimate the water-processing rate of these bivalves properly. Water processing by benthic suspension feeders can be of great importance in shallow coastal areas (Cloern 1982, Officer et al. 1982). However, the attempts made to determine clearance rates (CR) of bivalves are often difficult to compare or interpret. Thus, reported CR for a $1 \mathrm{~g}$ blue mussel Mytilus edulis vary from approximately 1 to more than $7 \mathrm{l} \mathrm{h}^{-1}$ (see Riisgård 2001b for a review). Measurements have been made under widely divergent conditions and by several different groups, and the conditions and procedures for performing such studies

\footnotetext{
${ }^{\mathrm{I}}$ This paper is written in memory of Serge Bougrier, who died tragically during the project.
}

are being discussed (Cranford 2001， Riisgård 2001a,b,d, Widdows 2001).

$\mathrm{CR}$, in suspension feeding bivalves varies due to many factors, such as the effects of water temperature, salinity and concentration of suspended particles (Jørgensen 1990, Bayne 1998, Riisgård 2001c). Further, the natural level of particulate material (Theisen 1977) as well as the level of contamination (Riisgård 2001a, Widdows 2001) at the site of collection of the experimental animals may affect measured CR. Therefore, comparisons which have been made without taking the ambient conditions in the experimental set-up into consideration may not be valid. Likewise, it has been argued that conditions in the laboratory may not reflect in situ filtration (Cranford 2001, Riisgård 2001d), as a suite of constantly changing environmental attributes may influence basic physiological parameters and thereby render comparisons difficult. At the present time, few in situ techniques are available and to our knowledge there are even fewer (or no) measurements 
on completely undisturbed or nonmanipulated bivalves in their natural habitat, since most of the published in situ methods involve some manipulation of the mussels before measuring CR (e.g. Cranford \& Hill 1999, Pouvreau et al. 2000).

A basic prerequisite for giving first estimates of $\mathrm{CR}$ or considering different regulation mechanisms is that the applied experimental methods are valid, i.e. that within defined conditions they actually measure CR. At present, in the discussion about valid bivalve $C R$, factors affecting $\mathrm{CR}$ and factors affecting CR measurements are confounded, which to some extent has polarised the discussion climate (see Cranford 2001, Riisgård 2001a,b,d, Widdows 2001).

The purpose of the present study is to compare CR measurements within and between batches of blue mussels by using different methods in parallel chambers. All chambers received water from the same source, and therefore had the same particle load and temperature. Three methods were compared: (1) the flow-through chamber method, (2) the bio-deposition method and (3) the indirect method. Experiments were performed on 2 different batches of mussels originating from France and Holland.

\section{MATERIALS AND METHODS}

Approximately $3 \mathrm{wk}$ prior to the start of the experiments, 40 to $50 \mathrm{~mm}$ long mussels were collected from the Oosterschelde estuary in Holland (bottom culture) and the Aiguillon Bay in France (suspended culture). Within $24 \mathrm{~h}$ of collection, mussels were cleared of epibionts and transported in cool boxes to the IFREMER laboratory in La Tremblade, France. In the laboratory, mussel batches were kept in separate acclimation tanks in running seawater taken from the Marennes-Oléron Bay, stored in outdoor ponds for sediment deposition, and enriched with Skeletonema costatum prior to being pumped into the acclimation tanks (see Table 1).

The experiments were carried out at the beginning of May 2001. During 3 consecutive days, the CR, defined as the volume of water cleared of all $100 \%$ efficiently retained particles per unit of time, was measured in parallel on 2 batches of mussels using 3 methods: (1) the flow-through method, (2) the bio-deposition method and (3) the indirect method. We divided ourselves into 3 teams, each using the method they had used in previous investigations. The Dutch team used the flow-through method, the French team used the bio-deposition method and the Danish team used the indirect method. In addition, the French team used the bio-deposition set-up and mussels and applied both the bio-deposition and flow-through methods
Table 1. Mytilus edulis. Conditions during acclimation with regard to temperature, total particulate material (TPM), particulate organic material (POM) and chl a

\begin{tabular}{|lrccr|}
\hline & $\begin{array}{c}\text { Temp. } \\
\left({ }^{\circ} \mathrm{C}\right)\end{array}$ & $\begin{array}{c}\mathrm{TPM} \\
\left(\mathrm{mg} \mathrm{l}^{-1}\right)\end{array}$ & $\begin{array}{c}\mathrm{POM} \\
\left(\mathrm{mg} \mathrm{l}^{-1}\right)\end{array}$ & $\begin{array}{r}\mathrm{Chl} \mathrm{a} \\
\left(\mu \mathrm{g} \mathrm{l}^{-1}\right)\end{array}$ \\
\hline Average & 12.2 & 9.7 & 1.9 & 12.5 \\
Minimum & 9.8 & 4.8 & 1.0 & 1.8 \\
Maximum & 15.8 & 25.9 & 4.2 & 22.2 \\
\hline
\end{tabular}

simultaneously. In all, there were 4 sets of results: from the flow-through (Dutch and French team), the biodeposition (French team) and the indirect method (Danish team); mussels used by the French team were identical for both methods applied. The experiments were carried out simultaneously over a period of $3 \mathrm{~d}$.

Flow-through chamber method. CR was measured using a flow-through system consisting of 16 quadratic grazing chambers with rounded edges, each having a volume of $390 \mathrm{ml}$ (Dutch team; for French team see bio-deposition method below). These were supplied with the same running seawater as in the acclimation tanks; 14 chambers were used for individual mussels and 2 chambers served as a control (Dutch team). Seawater enriched with phytoplankton was pumped to a mixing chamber and through the grazing chambers at a manually regulated flow rate (average: $202 \mathrm{ml} \mathrm{min}^{-1}$, range: 131 to $240 \mathrm{ml} \mathrm{min}^{-1}$; Dutch team). Prior to the measurements, mussels were taken from the laboratory maintenance tank and acclimated in the grazing chambers for at least $1 \mathrm{~h}$. Water was sampled from the outflow of both control chambers and chambers with mussels several times each day that measurements were taken. Particle concentrations of the samples were measured electronically, at least 3 times per sample, using a Coulter counter ID with a $100 \mu \mathrm{m}$ aperture tube and the lower threshold set to $4 \mu \mathrm{m}$. One measurement series consisted of 2 replicate water samples from each of the 7 chambers with mussels from Aiguillon as well as the 7 chambers with mussels from Oosterschelde and the 2 control chambers, and lasted ca. $3 \mathrm{~h}$ with ca. $1 \mathrm{~h}$ between each replicate. Flow rates in the chambers were measured as the water samples were taken. In total, 4 measurement series were carried out. CR was calculated as follows (Hildreth \& Crisp 1976):

$$
\mathrm{CR}=\left[\left(C_{\text {in }}-C_{\text {out }}\right) / C_{\mathrm{s}}\right] \times Q
$$

where $C_{\text {in }}$ is inflow particle concentration (here considered to be equal to the outflow concentration of the control chambers), $C_{\text {out }}$ is outflow concentration, $C_{\mathrm{s}}$ is concentration surrounding the mussel (here considered to be equal to the outflow concentration) and $Q$ is flow rate. 
In order to test whether the geometry of the grazing chamber caused recirculation of water, the Dutch team performed a series of experiments with different flow rates (43 to $381 \mathrm{ml} \mathrm{min}{ }^{-1}$ ) through the chambers. In addition to Eq. (1), CR were calculated using Eq. (2) (Riisgård 2001b):

$$
\mathrm{CR}=\left[\left(C_{\text {in }}-C_{\text {out }}\right) / C_{\text {in }}\right] \times Q
$$

Bio-deposition method. CR was determined on the basis of egested and rejected inorganic material. At least $1 \mathrm{~h}$ prior to the start of the experiment, mussels were transferred from the acclimation tanks to a system of 15 separate plastic rectangular trays with round corners and a volume of $800 \mathrm{ml}$, and supplied with the same running seawater as in the acclimation tanks. Individual mussels were laid on a PVC plate and a glass cover slip was positioned on a ball of putty so as to separate true faeces from pseudofaeces. Three empty trays were used as controls, and flow rates through all the trays were regulated manually (average: $145 \mathrm{ml} \mathrm{min}^{-1}$, range: 95 to $195 \mathrm{ml} \mathrm{min}^{-1}$ ). Total particulate matter (TPM), particulate inorganic matter (PIM) and particulate organic matter (POM; as the difference between TPM and PIM) were determined from seawater samples collected from the outflow of the control trays at the beginning and end of each experiment. Samples were filtered on Whatman ${ }^{\circledR}$ GF/C filters with a retention efficiency of $1.2 \mu \mathrm{m}$, dried $\left(60^{\circ} \mathrm{C}\right.$ for $\left.24 \mathrm{~h}\right)$, weighed and burnt to ash $\left(450^{\circ} \mathrm{C}\right.$ for $4 \mathrm{~h}$ ) before final weighing. Water concentrations of TPM, PIM and POM during the experiment were estimated as being an average of initial and final concentrations. Pseudofaeces and faeces produced by each mussel at the end of the experiment (after $2 \mathrm{~h}$ ) were collected separately by pipetting. Samples were homogenised and treated as already described for the water samples. Measurements were performed on 5 sets of 15 mussels, alternating between 7 Oosterschelde +8 Aiguillon mussels, and 8 Oosterschelde +7 Aiguillon mussels in each set. CR was calculated as in Hawkins et al. (1996):

$$
\mathrm{CR}=(\mathrm{IRR}+\mathrm{IER}) / \mathrm{PIM}
$$

where IRR is inorganic rejection rate (pseudofaeces) and IER is inorganic egestion rate (faeces).

Indirect method. CR was determined from the exponential decline in particle concentration over time in a closed container. A system of 16 cylindrical 21 jars was placed in a tank with running seawater and supplied with the same running seawater as in the acclimation tanks. Mussels were placed individually in 14 jars with a water volume of ca. 1.7 l. Water supply to the jars was cut off for 30 to $45 \mathrm{~min}$. and water mixing was ensured by air bubbling. The exponential decline in particle concentration in the jars over time was followed by a count of particles using an Elzone ${ }^{\circledR} 5380$ particle counter mounted with a $95 \mu \mathrm{m}$ orifice tube, with the lower threshold set to $4 \mu \mathrm{m}$; each sample was counted at least 3 times. After each experiment, water flowthrough was resumed for at least $1 \mathrm{~h}$ before a new experiment was performed. Two jars were used as controls, and no significant reduction in particle concentration over time was observed. Three series of experiments were carried out on an equal number of mussels from each origin, amounting to a total of 18 Aiguillon and 20 Oosterschelde mussels. CR was determined 2 to 4 times per individual as in Riisgård (2001b):

$$
\mathrm{CR}=V / t \times \ln \left(C_{\mathrm{o}} / C_{t}\right)
$$

where $V$ is the volume of the beaker, $t$ is time and $C_{0}$ and $C_{t}$ are particle concentrations at times 0 and $t$, respectively. An exponential line was fitted to the decline in algal cell concentration over time and only experiments with an $\mathrm{r}^{2}$ value $>0.95$ were considered.

Other analyses. After the experiments, the dry body weight (DW) of all experimental animals and shell length $(L)$ of all mussels, except those used in the biodeposition experiments, were determined. Based on these data, the condition index (CI) was calculated as:

$$
\mathrm{CI}=\mathrm{DW} / L^{3}
$$

To test for differences in CR between method and origin, an ANOVA was used with Method (flowthrough Dutch team, flow-through French team, biodeposition French team, indirect Danish team) and Origin (Aiguillon, Oosterschelde) as factors. Repeated measurements on the same mussel by the Dutch and Danish teams were averaged. In order to comply with the assumption of homogeneity of variances, data were cosine transformed.

The gill size of 13 Aiguillon and 11 Oosterschelde randomly selected mussels was measured (shell length differed) in the experiments using the indirect method. Mussels were relaxed with an isotonic solution of magnesium chloride and left in the solution until they did not respond to disturbances. The gills were excised and a photograph of the gill was taken with a digital camera. The gills were placed next to a ruler that was visible in the photographs. The photographs were transferred to a computer and the surface area of the gill was determined using the public domain NIH Image program (US National Institute of Health; available at http://rsb.info.nih.gov/nih-image/). The gross gill surface area $(A)$ was estimated from the area of 1 lamella of the outer demibranch multiplied by 8 , since the 4 demibranches are assumed to be of equal size (Møhlenberg \& Riisgård 1979). A gross gill surface area index (GI) was calculated from these data as follows:

$$
\mathrm{GI}=A / L^{2}
$$




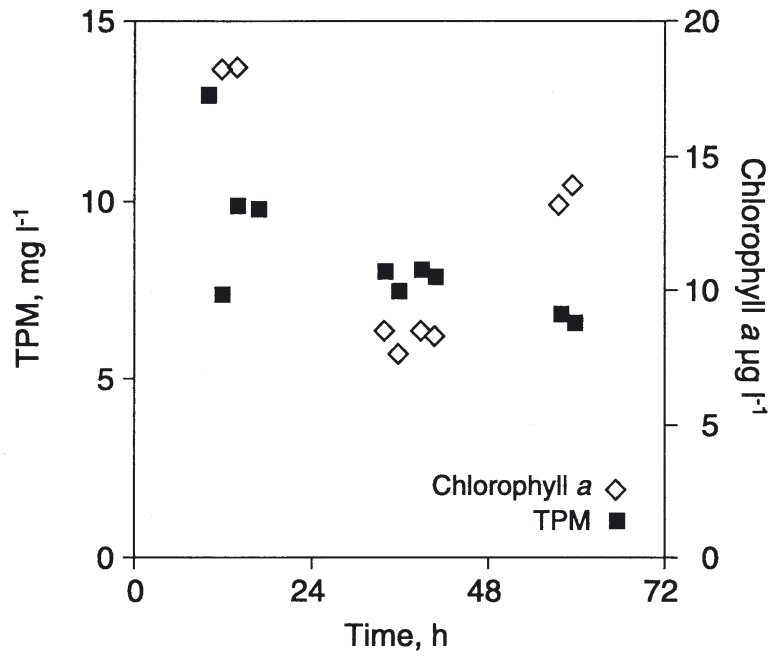

Fig. 1. Concentrations of total suspended particulate material (TPM) and chl a during the experiments. Data are from the bio-deposition experiment conducted by the French team

\section{RESULTS}

\section{Experimental conditions}

During experiments, the mean temperature was $15.2^{\circ} \mathrm{C}$ (range: 14.6 to $16.0^{\circ} \mathrm{C}$ ). There was more variation, especially on Day 1, in TPM and chl a concentrations (Fig. 1) and particle concentration (Fig. 2). Despite the fact that mussels were taken from the same 2 batches, there was a significant difference in DW between mussels (ANOVA, p < 0.001), and a Fischer Protected Least Significant Difference (PLSD) post-hoc test ( $5 \%$ level) showed that there were differences in dry weight both between the places of origin and the methods used (Table 2). CR were thus normalised to a $1 \mathrm{~g}$ standard mussel using an allometric factor of 0.67 (Jørgensen 1990, Bayne 1998, Riisgård 2001b).

\section{Clearance rate methods}

CR were on average $3.2 \mathrm{l} \mathrm{g}^{-1} \mathrm{~h}^{-1}$ using the bio-deposition method on mussels from Aiguillon Bay and 2.21 $\mathrm{g}^{-1} \mathrm{~h}^{-1}$ for mussels from Oosterschelde. These were lower than CR obtained with either the flow-through method (using Eq. 1) or the indirect method (Table 3). Statistical testing revealed significant differences between CR ( $p=0.0016)$. The post-hoc test showed that on a $5 \%$ level, CR measured with the bio-deposition method were significantly lower than rates measured with the other methods, and it also

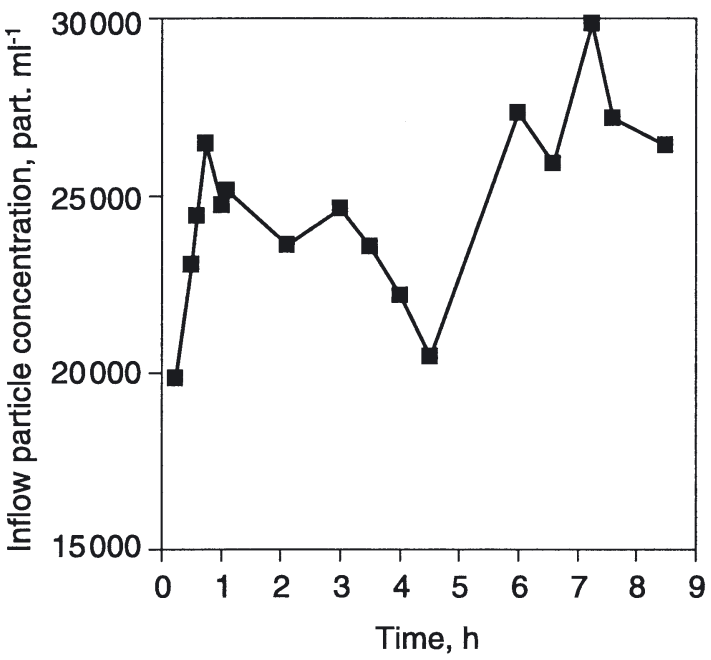

Fig. 2. Particle concentration in the inflow from the control chamber during Day 1. Data are from the flow-through experiment conducted by the Dutch team

indicated a significant difference in CR between mussels from Aiguillon Bay and Oosterschelde estuary ( $\mathrm{p}=$ 0.0026). Further, CR measured in the bio-deposition set-up on identical mussels but with different methods, i.e. bio-deposition and flow-through (using Eq. 1), gave significantly different results.

Results of experiments with varying flow rate through the grazing chambers are shown in Fig. 3. When Eq. (1) is used, estimates of CR are independent of flow rate $\left(\mathrm{p}=0.15\right.$; average of $\left.4.7 \pm 0.4 \mathrm{l} \mathrm{h}^{-1}\right)$, whereas when Eq. (2) is used, CR are dependent on flow rate up to a certain level. Applying an Ivlev function to fit the data for Eq. (2) calculations of CR results in a $\mathrm{CR}_{\max }$ of $3.61 \mathrm{~h}^{-1}$.

\section{Origin of mussels}

Gross gill area was related to the length of the mussel (Fig. 4). Using the gross gill surface area index (GI) allowed for comparison between mussels of different origin. The GI $(p<0.0001)$ as well as the CI $(p=0.034)$ were significantly different between Aiguillon and

Table 2. Mytilus edulis. Mean weight (and range) in mg of mussels used for the experiments. ${ }^{*}$ Significant difference $(\mathrm{p}<0.05)$ of measurements in that column/row compared to the other columns/rows. Mussels in the column 'Biodeposition' were also used for flow-through measurements by the French team

\begin{tabular}{|lcll|}
\hline & Bio-deposition * & Flow-through** & Indirect* $^{*}$ \\
\hline Aiguillon & $339(106-563)$ & $411(175-703)$ & $614(412-973)$ \\
Oosterschelde* $^{*}$ & $445(131-690)$ & $682(427-951)$ & $719(477-1101)$ \\
\hline
\end{tabular}


Table 3. Mytilus edulis. Mean clearance $\pm \mathrm{SD}$ (and range) of standard $1 \mathrm{~g}$ mussels $\left(\mathrm{l} \mathrm{g}^{-1} \mathrm{~h}^{-1}\right)$ as a function of method and origin. Clearance was estimated with the flow-through method using both the flow-through set-up (Dutch team) and the bio-deposition set-up (French team). "Significant difference $(\mathrm{p}<0.05$, for cosine transformed data) of measurements in this column/row compared to the other columns/rows

\begin{tabular}{|lcccc|}
\hline & Bio-deposition* & $\begin{array}{c}\text { Flow-through } \\
\text { (French team) }\end{array}$ & $\begin{array}{c}\text { Flow-through } \\
\text { (Dutch team) }\end{array}$ & Indirect/clearance \\
\hline Aiguillon & $\begin{array}{l}3.2 \pm 1.5 \\
(1.6-8.1, \mathrm{n}=37)\end{array}$ & $\begin{array}{c}11.0 \pm 7.6 \\
(1.2-31.0, \mathrm{n}=34)\end{array}$ & $\begin{array}{c}9.6 \pm 1.8 \\
(5.4-13.6, \mathrm{n}=27)\end{array}$ & $\begin{array}{c}9.5 \pm 1.3 \\
(7.2-11.9, \mathrm{n}=18)\end{array}$ \\
Oosterschelde* & $2.2 \pm 1.0$ & $5.8 \pm 2.8$ & $5.0 \pm 1.2$ & $5.0 \pm 0.7$ \\
& $(0.5-4.2, \mathrm{n}=34)$ & $(1.3-11.5, \mathrm{n}=34)$ & $(2.8-7.0, \mathrm{n}=28)$ & $(3.6-6.7, \mathrm{n}=20)$ \\
\hline
\end{tabular}

Oosterschelde mussels (Table 4). Likewise, the gross gill area and weight-specific CR were significantly $(\mathrm{p}<$ 0.0001) different in relation to mussel origin. However, while the mean weight-specific CR of mussels from Oosterschelde was only $52 \%$ of the mean rate of mussels from Aiguillon Bay, it was $76 \%$ on a gill area specific basis. For all mussels where length was measured, there was a significant difference as a function of mussel origin for weight (Table $2, \mathrm{p}<0.0001$ ) and CI (Table 5, p < 0.0001) but not for shell length (Table 5, $\mathrm{p}=0.053)$.

\section{DISCUSSION}

Under conditions of identical temperature, salinity and TPM concentrations, our experiments showed that estimates of CR depend on the method used, with

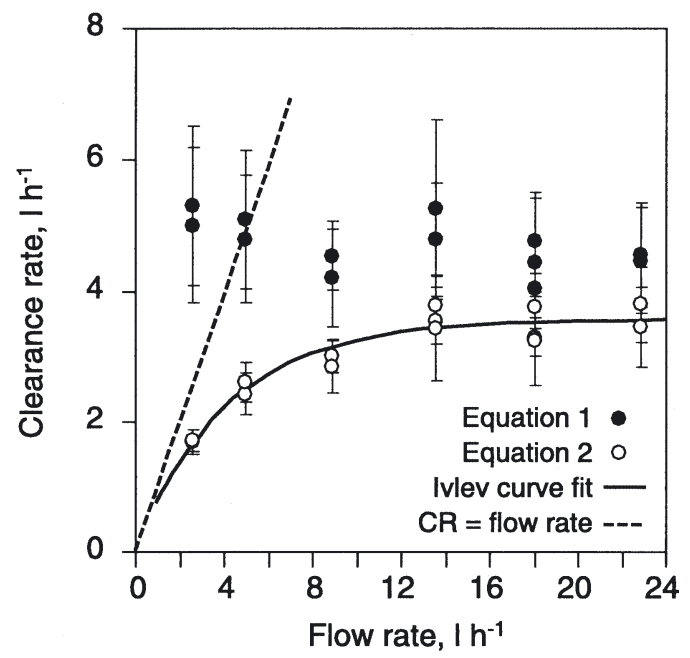

Fig. 3. Mytilus edulis. Mean $( \pm \mathrm{SD}) \mathrm{CR}\left(\mathrm{l} \mathrm{h}^{-1}\right)$ in 4 mussels as a function of flow rate in the flow-through set-up. CR (CR) is calculated either as a steady state using Eq. (1) (Hildreth \& Crisp 1976) or from Eq. (2) (Riisgård 2001b). For Eq. (2), data is fitted to an Ivlev function $\left(\mathrm{CR}=3.57 \times\left[1-\mathrm{e}^{-0.24 \text { flow }}\right]\right.$,

$$
\left.r^{2}=0.92\right)
$$

the bio-deposition method giving significantly lower rates than either the flow-through (using Eq. 1) or the indirect methods.

There may be several reasons for the lower CR obtained with the bio-deposition method as compared to the other methods, even those using identical mussels and experimental conditions. In the bio-deposition method, seston in the grazing chambers is trapped on a filter having a nominal retention efficiency of approximately $1 \mu \mathrm{m}$, which can be expected to gradually decrease to even smaller sizes as the filter progressively clogs during filtration. However, in blue mussels, retention efficiency of the filtering apparatus rapidly decreases below $4 \mu \mathrm{m}$ (Møhlenberg \& Riisgård 1978). Hence the bio-deposition method may overestimate particle concentration available to the mussels and consequently underestimate CR according to Eq. (3). That overestimation of available particle concentration was a problem could be seen from the flow-through experiments carried out by the French team. In addition to determining particle concentration $>4 \mu \mathrm{m}$, par-

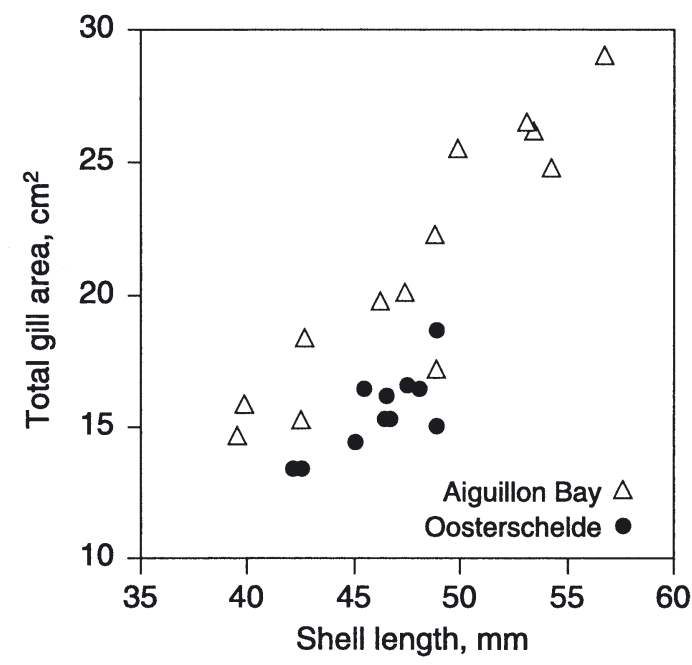

Fig. 4. Mytilus edulis. Total gill area in blue mussels as a function of shell length. Mussels measured were used in experiments with the indirect method 
Table 4. Mytilus edulis. Mean specific CR \pm SD per $1 \mathrm{~g}$ standard mussel $\left(\mathrm{l} \mathrm{g}^{-1} \mathrm{~h}^{-1}\right)$ or per $1 \mathrm{~cm}^{2}$ gill area $\left(\mathrm{cm}^{-2} \mathrm{~h}^{-1}\right)$ in 13 Aiguillon and 11 Oosterschelde mussels using the indirect method to determine CR. Condition index (CI) was calculated using dry weight (DW) in mg and length $(L)$ in $\mathrm{cm}$ and gill area index (GI) was calculated using $\mathrm{cm}$. A: gross gill surface area. Oosterschelde mussels are significantly different $\left({ }^{*} \mathrm{p}<0.05\right)$ for all parameters

\begin{tabular}{|lcccc|}
\hline & $\begin{array}{c}\text { Weight } \\
\text { specific } \\
\text { clearance }\end{array}$ & $\begin{array}{c}\text { Area } \\
\text { specific } \\
\text { clearance }\end{array}$ & $\begin{array}{c}\text { Condition } \\
\text { index } \\
\left(\mathrm{CI}=\mathrm{DW} / L^{3}\right)\end{array}$ & $\begin{array}{c}\text { Gill area } \\
\text { index } \\
\left(\mathrm{GI}=\mathrm{A} / L^{2}\right)\end{array}$ \\
\hline Aiguillon $_{\text {Oosterschelde }^{*}}$ & $9.5 \pm 1.4$ & $0.34 \pm 0.04$ & $6.21 \pm 1.72$ & $0.92 \pm 0.08$ \\
& $4.9 \pm 0.6$ & $0.26 \pm 0.03$ & $7.44 \pm 0.61$ & $0.73 \pm 0.04$ \\
\hline
\end{tabular}

Table 5. Mytilus edulis. Mean (and range) of length ( $\mathrm{mm}$ ) and condition index (CI) of mussels used in the flow-through and indirect experiments

\begin{tabular}{|lcccc|}
\hline & \multicolumn{2}{c}{ Flow-through } & \multicolumn{2}{c|}{ Indirect } \\
& Length & CI & Length & CI \\
\hline Aiguillon & $44.2(35.3-55.0)$ & $4.7(3.4-5.7)$ & $47.1(39.5-56.8)$ & $5.9(4.4-10.1)$ \\
Oosterschelde & $46.5(41.4-52.8)$ & $6.8(4.9-9.6)$ & $46.7(41.8-54.3)$ & $7.1(4.3-9.7)$ \\
\hline
\end{tabular}

ticle concentration $>2 \mu \mathrm{m}$ was also determined and use of these data resulted in approximately $10 \%$ lower CR (data not shown). Faecal and pseudofaecal material may be swept away by the flow-through and by the exhalent current, which will also result in an underestimation of the $C R$, since the material which has been swept away is eliminated from the calculations (Iglesias et al. 1998). Another difference compared to the other methods is that bio-deposits are collected over a $2 \mathrm{~h}$ period and the corresponding water samples were sampled at the beginning and end of that period. This has 2 implications: (1) The CR estimate of the bio-deposition method is an integration covering a longer time span including periods of potential inactivity (Bougrier et al. 1998), whereas the data from the other methods covered shorter periods of time and were taken mainly from mussels that were actively filtering. (2) Due to gut passage times of 0.5 to $0.7 \mathrm{~h}$ (Willows 1992, Hawkins et al. 1996), the measured seston concentrations of the water only partly reflect the ingested material. Under variable seston conditions, such as during the first day of the present experiment (see Figs. 1 \& 2), this may influence the CR estimate (Iglesias et al. 1998). Sedimentation may also constitute a significant problem when suspended material contains a high proportion of particles with high densities (Iglesias et al. 1998), but since the water used in the experiments had passed through deposition tanks and control trays were set up with an empty shell, we do not think that this was a major source of error. Finally, it has been argued that the flow pattern and geometry of the chamber may cause refiltration and thus result in an underestimation of true clearance (Riisgård 2001d). A test in a controlled flume could be used to evaluate the potential magnitude of this problem (Riisgård 2001d). We encourage further evaluation and development of the bio-deposition method, since it is one of the few existing ways to perform in situ or semi in situ CR measurements.

The flow-through and indirect methods gave identical CR results for both Aiguillon and Oosterschelde mussels. However, when using the flow-through method, it is important that there is accordance between experimental set-up, including geometry of the chamber, and the equation used for calculating $\mathrm{CR}$. When using Eq. (1), it is thus assumed that the geometry of the chamber allows for a steady state and total mixing of the water (Hildreth \& Crisp 1976, Vismann 1990, Riisgård 2001b). On the other hand, in Eq. (2), it is assumed that the geometry of the chamber facilitates optimal flow-through and does not allow recirculation and thus refiltration of water. This implies that once the inflowing water has passed the mussel inhalant siphon, it must not pass it again (Riisgård 2001b). We tested the geometry of the Dutch experimental chambers by changing flow rates and calculating $\mathrm{CR}$ with both equations. Only at very low flow rates were $\mathrm{CR}$ equal to flow rates, and the CR calculated with Eq. (2) were lower than rates calculated with Eq. (1). This indicates that the geometry of the grazing chamber was not suitable for using Eq. (2). Rather, a constant $\mathrm{CR}$ at all flow rates indicates that steady state conditions with instantaneous mixing were accomplished. It is thus of great importance that these prerequisites for using the flow-through method, with either of the equations, are met before measuring CR. Applying Eq. (2) to the present data set would thus have given $\mathrm{CR}$ of $4.0 \pm 1.5$ and $6.3 \pm 3.0 \mathrm{l} \mathrm{h}^{-1} \mathrm{~g}^{-1}$ (French team) and $3.8 \pm 0.8$ and $6.6 \pm 1.1 \mathrm{l} \mathrm{h}^{-1} \mathrm{~g}^{-1}$ (Dutch team) for mussels from Oosterschelde and Aiguillon Bay, respectively - which is significantly ( $\mathrm{p}<$ 0.0001) lower than the rates calculated using Eq. (1).

Previous comparisons of methods have, in general, shown good correlation between methods. Pouvreau et al. (1999) found no difference between CR obtained with the flow-through method as opposed to the suction method (Møhlenberg \& Riisgård 1978), which as is the case for the indirect method also uses a closed container and is calculated using Eq. (4). Similarly, Urrutia 
et al. (1996) made a linear regression between CR estimates obtained with the bio-deposition as opposed to the flow-through method in cockles Cerastoderma edule and found that the slope was no different between the two, nor was the intercept different from zero, which is in contrast to our findings. Recalculating their data to CR for a $0.5 \mathrm{~g}$ standard cockle in a TPM range of 2 to $100 \mathrm{mg} \mathrm{l}^{-1}$ gives values between 0.7 to $1.5 \mathrm{l} \mathrm{h}^{-1}$. These are substantially lower than the $7.1 \mathrm{l} \mathrm{h}^{-1}$ obtained by Møhlenberg \& Riisgård (1979) for a similar sized cockle. Not all comparisons have, however, given full correlation between methods. Thus, Iglesias et al. (1998), in 1 of 4 trials, found a significant difference between the indirect and the bio-deposition method of measuring cockles, but the reported CR were approximately $30 \%$ of the rates reported by Møhlenberg \& Riisgård (1979) for similarly sized mussels and comparable TPM levels.

In addition to the difference between methods, we also found that CR depends on the origin of the experimental animals. This difference can partly be explained by the difference in weight and condition index of the mussels. But some of the difference was also attributable to the difference in gross gill area, which has previously been shown to correlate with CR (Meyhöfer 1985, Jones et al. 1992, Pouvreau et al. 1999). Gross gill area may vary between populations of bivalves, even those within a short distance from one another, if particulate matter concentration differs (Barillé et al. 2000). The larger gross gill area of the Aiguillon mussels could, however, only explain $50 \%$ of the difference between the 2 batches of mussels. The remaining difference cannot be explained entirely by data from this study. The 2 batches of mussels differ in several aspects: the Aiguillon mussels were collected from a suspended culture line, whereas the mussels from Oosterschelde were collected on the bottom. It is well accepted that mussel CR depends on particulate matter concentration (Widdows et al. 1979, Riisgård 1991) and that mussels of different origin can manage high concentrations of PIM differently, depending on the size of the labial palps (Theisen 1977). That the 2 groups of mussels were different with regard to the handling of particles was evident from the experiments with the bio-deposition method. The rejection rate of Oosterschelde mussels was $48 \%$ of the total filtration rate (using the notation of Iglesias et al. 1998), whereas it was $56 \%$ in Aiguillon mussels. Finally, differences in the physiological state (pre- and postspawning) between the mussels may have also had an impact.

The CR obtained in this study are much higher than rates obtained in previous investigations with mussels from the same area in Holland (Smaal \& Twisk 1997, Smaal \& Vonck 1997, Smaal et al. 1997), or nearby areas like the Marennes-Oléron Bay in France (Hawkins et al. 1996; based on their findings of the relation between CR and TPM). The measured CR are, however, comparable to (Oosterschelde mussels) or slightly higher than (Aiguillon mussels) results from other studies performed under controlled conditions in the laboratory (Kiørboe \& Møhlenberg 1981, Riisgård 2001b). The lower CR obtained in the studies from Oosterschelde were in part obtained using Eq. (2) (Smaal \& Twisk 1997, Smaal \& Vonck 1997) and it cannot be ruled out that some refiltration of water may have occurred in the experiments. However, similar rates were also found by Smaal et al. (1997) using a different method in which in- and outflow samples were taken overnight (16 h).

We have in the present study only focussed on CR and comparability of results using different methods and have not tested other aspects of the methods. For example, the bio-deposition method clearly produces other important physiological information regarding ingestion, absorption and rejection of particles. Likewise, for the same amount of effort involved the indirect method produces fewer data than the flowthrough method-a topic not dealt with in our investigation. The problems with keeping constant particle concentrations in the experimental containers using the indirect method have, however, been addressed in this study by applying a semi-static approach, where the water supply to the chambers was only cut off for short periods.

In summary, our results show that the bio-deposition method will give significantly lower CR than the flowthrough method and the indirect method, when all methods are employed as in the present study. When using a flow-through set-up for measuring $\mathrm{CR}$, the water circulation in the experimental chambers should be carefully examined and calculations performed with the proper equation. The problems with keeping a constant food or particle concentration using the indirect method can be overcome by applying semi-static conditions as was done in the present study. Our results call for a thorough examination of previous investigations. Further, the gross gill surface area and thus the origin of the mussels are of major importance to maximum clearance capacity and should be considered as factors causing variation among reported data.

Acknowledgements. We thank Laboratoire Conchylicole de Poitou-Charentes for their hospitality during the experiments. The study has been carried out with financial support from the Commission of the European Communities, Agriculture and Fisheries (FAIR) specific RTD programme CT 98-4201 ESSENSE. It does not necessarily reflect its views and in no way anticipates the Commission's future policy in this area. 


\section{LITERATURE CITED}

Barillé L, Haure J, Cognie B, Leroy A (2000) Variations in pallial organs and eulatero-frontal cirri in response to high particulate matter concentrations in the oyster Crassostrea gigas. Can J Fish Aquat Sci 57:837-843

Bayne BL (1998) The physiology of suspension feeding by bivalve molluscs: an introduction to the Plymouth 'TROPHEE' workshop. J Exp Mar Biol Ecol 219:1-19

Bougrier S, Collet B, Geairon P, Geffard O, Héral M, Deslous Paoli JM (1998) Respiratory time activity of the Japanese oyster Crassostrea gigas (Thunberg). J Exp Mar Biol Ecol 219:205-216

Cloern JE (1982) Does the benthos control phytoplankton biomass in South San Francisco Bay? Mar Ecol Prog Ser 9: 191-202

Cranford PJ (2001) Evaluating the 'reliability' of filtration rate measurements in bivalves. Mar Ecol Prog Ser 215:303-305

Cranford PJ, Hill PS (1999) Seasonal variation in food utilization by the suspension-feeding bivalve molluscs Mytilus edulis and Placopecten magellanicus. Mar Ecol Prog Ser 190:223-239

Hawkins AJS, Smith RFM, Bayne BL, Héral M (1996) Novel observations underlying the fast growth of suspensionfeeding shellfish in turbid environments: Mytilus edulis. Mar Ecol Prog Ser 131:179-190

Hildreth DJ, Crisp DJ (1976) A corrected formula for calculation of filtration rate of bivalve molluscs in an experimental flowing system. J Mar Biol Assoc UK 56:111-120

Iglesias JIP, Urrutia MB, Navarro E, Ibarrola I (1998) Measuring feeding and absorption in suspension-feeding bivalves: an appraisal of the biodeposition method. J Exp Mar Biol Ecol 219:71-86

Jones HD, Richards OG, Southern TA (1992) Gill dimensions, water pumping rate and body size in the mussel Mytilus edulis L. J Exp Mar Biol Ecol 155:213-237

Jørgensen CB (1990) Bivalve filter feeding: hydrodynamics, bioenergetics, physiology and ecology. Olsen \& Olsen, Fredensborg

Kiørboe T, Møhlenberg F (1981) Particle selection in suspension-feeding bivalves. Mar Ecol Prog Ser 5:291-296

Meyhöfer E (1985) Comparative pumping rates in suspensionfeeding bivalves. Mar Biol 85:137-142

Møhlenberg F, Riisgård HU (1978) Efficiency of particle retention in 13 species of suspension feeding bivalves. Ophelia 17:239-246

Møhlenberg F, Riisgård HU (1979) Filtration rate, using a new indirect technique, in thirteen species of suspensionfeeding bivalves. Mar Biol 54:143-147

Officer CB, Smayda TJ, Mann R (1982) Benthic filter feeding: a natural eutrophication control. Mar Ecol Prog Ser 9:203-210

Editorial responsibility: Otto Kinne (Editor),

Oldendorf/Luhe, Germany
Pouvreau S, Jonquières G, Buestel D (1999) Filtration by the pearl oyster Pinctada margaritifera, under conditions of low seston load and small particle size in a tropical lagoon habitat. Aquaculture 176:295-314

Pouvreau S, Bodoy A, Buestel D (2000) In situ suspension feeding behaviour of the pearl oyster, Pinctada margaritifera: combined effects of body size and weather-related seston composition. Aquaculture 181:91-113

Riisgård HU (1991) Filtration rate and growth in the blue mussel Mytilus edulis Linneaus: dependence on algal concentration. J Shellfish Res 10:29-35

Riisgård HU (2001a) Inaccurate bivalve CR measurements: a reply. Mar Ecol Prog Ser 221:307-309

Riisgård HU (2001b) On measurement of filtration rates in bivalves - the stony road to reliable data: review and interpretation. Mar Ecol Prog Ser 211:275-291

Riisgård HU (2001c) Physiological regulation versus autonomous filtration in filter-feeding bivalves: starting points for progress. Ophelia 54:193-209

Riisgård HU (2001d) The stony road to reliable filtration rate measurements in bivalves: a reply. Mar Ecol Prog Ser 215: 307-310

Smaal AC, Twisk F (1997) Filtration and absorption of Phaeocystis cf globosa by the mussel Mytilus edulis L. J Exp Mar Biol Ecol 209:33-46

Smaal AC, Vonck APMA (1997) Seasonal variation in C, N and $\mathrm{P}$ budgets and tissue composition of the mussel Mytilus edulis. Mar Ecol Prog Ser 153:167-179

Smaal AC, Vonck APMA, Bakker M (1997) Seasonal variation in physiological energetics of Mytilus edulis and Cerastoderma edule of different size classes. J Mar Biol Assoc UK 77:817-838

Theisen BF (1977) Feeding rate of Mytilus edulis L. (Bivalvia) from different parts of Danish waters in water of different turbidity. Ophelia 16:221-232

Urrutia MB, Iglesias JIP, Navarro E, Prou J (1996) Feeding and absorption in Cerastoderma edule under environmental conditions in the Bay of Marennes-Oleron (western France). J Mar Biol Assoc UK 76:431-450

Vismann B (1990) Field measurements of filtration and respiration rates in Mytilus edulis L.: an assessment of methods. Sarsia 75:213-216

Widdows J (2001) Bivalve CR: inaccurate measurements or inaccurate reviews and misinterpretation. Mar Ecol Prog Ser 221:303-305

Widdows J, Fieth P, Worrall CM (1979) Relationships between seston, available food and feeding activity in the common mussel Mytilus edulis. Mar Biol 50:195-207

Willows RI (1992) Optimal digestive investment: a model for filter feeders experiencing variable diets. Limnol Oceanogr $37: 829-847$

Submitted: February 19, 2003; Accepted: October 25, 2003 Proofs received from author(s): February 2, 2004 